\title{
A Critique of 'Bottom-up' Peacebuilding: Do Peaceful Individuals Make Peaceful Societies?
}

\author{
Sandrine Lefranc
}

This chapter is concerned with dialogue-based post-conflict practices currently being promoted vigorously by certain international organizations (and in some of this book's chapters). On the one hand, there is "transitional justice" with its cornerstone forums, deemed truth and reconciliation commissions. On the other hand, there are various "bottom-up" peacebuilding techniques (local dialogues, coexistence programs, conflict resolution training, and so on). Generally speaking, these "bottom-up" approaches work to transform individual prejudices and emphasize relations amongst "ordinary people". The shared objective of these practices is to construct peace that proves more "sustainable" than the usual international peacemaking and peacebuilding policies that focus upon political elites and institutional reform.

I seek to demonstrate that it is through sociological analysis of the people and organizations promoting these approaches, rather than a strict evaluation of the programs' efficacy, that can reveal certain surprising characteristics of the groups involved. These groups are quite specific and diverse: religious evangelical and Anabaptist groups, activist groups fighting for peacebuilding via education, and professionals from realms such as para-judiciary conflict resolution and individual therapy. I also aim to show that in exploring these programs' origins, it becomes possible to unveil one of their singular traits: an underlying individualist, relationist conception of social functioning and change. The individual becomes the only true agent of peace; a peace that is supposed to become a shared culture thanks to a gradual social diffusion, starting with the select few who are immediately connected with the international programs in question. Two non-governmental organizations will here bear witness to the usage of techniques borrowed directly from individual therapy practices. Finally, I point to the link between 'bottom-up' approaches and the more institutional forms of peacebuilding. I argue that "transitional justice" is grounded in this conception of peace via the individual, and that, ultimately, this works to de-politicize peacebuilding processes.

\section{The Invention of an International Norm: Peace via Broad Dialogue}

The extreme complexity of post-conflict conditions and contexts suggests that "transition towards peace" can hardly be subjected to any kind of political or social engineering. Recurring and violent intrastate conflicts in regions like the African Great Lakes, Central America or the Near East attest to this. Uninterrupted periods of extreme political violence are, however, the current object of numerous "good practices" offered systematically to local actors by international organizations or various NGOs as examples of how to build peace. The winning faction or recognized government are thus offered varied post-conflict devices that are more or less integrated into the peace treaties, institutional reform programs, a cessation of hostilities, or plans for economic development. Some devices individualize 
responsibility for violent acts that are defined as crimes (judicial proceedings, amnesty, or compensation to victims of gross human rights violations). Others focus upon building or re-building the conditions for coexistence.

These are the kinds of practices and policies that interest me here, and specifically those that emphasize dialogue via an institutionalized "truth commission" where experts organize public debates about History and victims reparations, or dialogue via conflict resolution training groups or exchanges between "ordinary people". The first method has been favoured by international organizations, occasionally integrated with juridical procedures under the concept of "transitional justice". Since the first experiences of the 1980s in Latin America, more than thirty commissions, all more or less of the same model, have worked to educate or inform populations about History; that is, they have worked to construct a minimally consensual understanding of the conflict and violent events.

The second type of practices are less institutionalized, but perhaps more ambitious. They seek to promote non-violent conflict resolution through the transformation of interpersonal relations and individual behaviors vis-à-vis the (former or not) antagonist; thus extending way beyond the knowledge of History. As their promoters do, we can call these practices peacebuilding from below, or 'bottom-up' peacebuilding. They take two key forms. First, "organized encounters" between "middle-level" elites (ethnic, religious, and intellectual leaders, heads of local NGOs, and so on) or "ordinary people" who often come from groups in conflict within a village or a region. The second form concentrates on conflict resolution training meant to teach the skills said to be necessary for preventing political violence. Within this group of practices, activities range from summer camps for adolescents, women centers, formation of local mediators, organization of "media for peace" (news and debates produced by ethnically-mixed teams, or soap operas starring children or families from antagonist groups trying to live peacefully), local development projects, to festivals and "dialogic research" (that is, research based upon local deliberation exercises). The objective of the dialogue may be or not the conflict. Ultimately, the idea is to write history collectively and/or to attenuate feelings of resentment.

These 'bottom-up' practices are not new, but they have gained in importance since the mid-1990s. More and more frequently, they are integrated with traditional development programs ("mainstreaming"). Specialized non-governmental organizations (NGOs) were created during the 1980s (Search for Common Ground, Conflict Management Group, Conciliation Resources, Interpeace, and so on) and the 1990s (Seeds of Peace, the International Center for Transitional Justice (ICTJ)). More recently, specific programs were set up within existing governmental or intergovernmental organizations (the United States Agency for International Development, the World Bank, the United Nations Development Programme), or within NGOs (Care, Caritas, World Vision, Oxfam, and so on).

This institutionalization of peacebuilding is reflected in several speeches and initiatives from various Secretary-Generals of the United Nations (beginning in 1992 with Boutros Boutros Ghali's Agenda for Peace). One can posit that peace via broad dialogue benefits from considerable legitimacy in international spaces working to intervene in "post-crisis" situations. This recognition is strengthened by the strong 
consonance between these peacebuilding approaches and the participatory ideologies found in the same professional milieus. Indeed, no international program today seems able to get under way without the active involvement of "Southern NGOs", or without the beneficiaries' input into defining the objectives (Cooke and Kothari, 2001). As such, the valorization of reconciliation between "ordinary people" is an element of a common sense that attaches importance to local initiatives and deliberative practices, and that claims the need to substitute imported resources with "indigenous" ones. For instance, the Conflict Management Group (now part of Mercy Corps) organized conflict resolution training sessions in parts of the Byumba province of Rwanda geared especially toward women and local leaders. The training sessions, provided by American experts and later by Rwandans, were based upon daily instances of conflict and proverbs supposedly condensing the local culture (Sommers and McClintock, 2003). 'Top-down' peacebuilding processes and practices that emphasize strictly the political elites and formal institutions have been criticized on a large scale, while simultaneously the ideas of deliberation and face-to-face dialogue have been promoted.

These practices and policies, as internationalized as they may be, do not "work". Or, to put it in more sociologically prudent terms, they are perceived favorably by those who enthusiastically promote them even when they confess their doubts regarding the efficiency of the measures. Transitional justice, arguably the most institutionalized and internationally recognized dialogue-oriented peacebuilding practice $^{1}$, has been the subject of careful assessments by its most zealous supporters. Desmond Tutu, president of the South African Truth and Reconciliation Commission, often repeated, and in opposition to his usual enthusiasm, that the TRC was merely a contribution to an unfinished process (Truth and Reconciliation Commission, 1999, I.5.6 ; Tutu, 1999). These doubts concerning the effectiveness of truth commissions are all the more legitimate when one considers the difficulties of the objectives and in measuring the commission's success: that perpetrators recognize their acts of political violence, the "appeasement" of victims, the decline of political violence, stabilization of the regime, generating a wide agreement over a common understanding of History, if not "reconciliation", and so on. In view of these wide-ranging objectives, even the TRC failed to produce satisfactory results (Chapman and van der Merwe, 2008).

The assessment difficulties are even more obvious when it comes to 'bottomup' approaches. Even the actors most invested in, and most professionally dependent upon, the implementation of 'bottom-up' peacebuilding programs concede the difficulty, if not the impossibility: "A lot of people get nervous about their efficiency: they wonder 'we're working at this small community level, how can you expect to have a big impact?'. (...). We ask to them: 'So how does your media program work?'-'Well, they answer, people will change their minds, and if they change their minds, then they will act in this way, or they will vote in this way'. (...) But we ask: 'Is it enough to do just change people's minds individually? Can you expect them automatically to go and do this and this?' "2

\footnotetext{
${ }^{1}$ So institutionalized and international that its model has come to nuance the principle and the applications of international criminal law in post-conflict situations (see Lefranc, 2009).

2 Interview, Collaborative for Development Action staff members, February 14, 2007, Cambridge (United States).
} 
However, this acknowledgement of the difficulties must not undermine the mobilizing capacity of the programs. Doubts are often quickly put aside, even by the most critical. ${ }^{3}$ The effectiveness of the programs is presented as a wager: a wager based upon the good will of the actors, and above all a wager based, as we will see, upon the ripple effects of local dialogue processes and of the diffusion of various representations. Because they cannot be evaluated, ${ }^{4}$ their effectiveness is conceived as "natural" or common sense; that is, as grounded in unquestioned assumptions about social change and interactions. As such, they can be promoted and legitimized as alternatives to dominant practices.

Indeed, it is their mutual critiques of 'top-down' approaches that constitute their unity. While we can distinguish them according to their degree of institutionalization, their visibility and their ambition, 'bottom-up' practitioners all claim that their approaches have wider and longer-term effects than international practices that seek and prioritize peace agreements between elites, or that promote a "liberal peace" of democratization and market economy (Paris, 2004). Political elites are bypassed, or at the very least not considered as the only peace vector. The promotion of truth commissions and local dialogues is thus intimately linked with a critique of all forms of external and coercive peacebuilding interventions. John W. McDonald, founder of an NGO once very active in peacebuilding activities (Institute for Multi-Track Diplomacy), derides governmental diplomacy as formal, masculine, and bureaucratic, powered by loyalty and conformity, fearful of open dialogue, and dealing with short-term power considerations (McDonald, 2002). Broad dialogue, on the other hand, is supposed to go beyond mutually stigmatizing representations or to foster a shared understanding of the recent conflict. Hence, as the argument goes, a "sustainable", "positive", and democratic peace is enabled, or at least, an agreement can be reached over the objectives of peace, coexistence, and future conflict prevention mechanisms.

The international success of 'bottom-up' approaches might be partly explained by the repeated claims that they represent an alternative to dominant modes of intervention. Within an international peace "market" that has become saturated and that has had to face many of its failures since the early 1990s, peacebuilding practices and policies that target "ordinary people" might not be conceived as this effective and commonsensical if it was not for their unity in critiques. Moreover, this internal critique of humanitarianism is articulated with and within the academic critique of the realist paradigm of international relations theory and its associated understandings of international intervention. Consequently, the critique can then articulate alternatives, like that of "human security" (David, 2000).

Indeed, it seems to be no coincidence that Mary Anderson, flag bearer of the critique "Do No Harm" that underlined the detrimental effects of humanitarian

\footnotetext{
3 Mary Anderson, one of the primary instigators of the critical reflection over humanitarian action (Anderson, 1999), oscillates between doubt and enthusiasm. During an interview (in February, 2007 at Cambridge, USA), she explained her departure from the American Friends Service Committee as caused by her understanding that "pleasant relationshipswith other cultures are not enough to change the world. See also Anderson and de Bock, 1999.

${ }^{4}$ Unless we speak of satisfaction surveys given to participants that seem to be clearly insufficient, yet a generalized evaluation technique (for example, see Search for Common Ground, 2002).
} 
interventions (Anderson, 1999), has played a significant role in promoting and legitimizing alternative intervention approaches. Her organization's research (Collaborative for Development Action), under the title of "Local Capacities for Peace", has become a source of reference and point of unity for the common practices of numerous actors involved in peacebuilding. ${ }^{5}$

The development of dialogue-oriented peace programs can thus be better understood as emanating partly out of the successes of a critical discourse. The invention of transitional justice and the multiplication of 'bottom-up' approaches to peacebuilding, but also the ease with which these 'alternatives' developed as professional markets and with which they became integrated in the funding networks of the same international organizations that they criticized, might lead us to a critique of an opportunist critical stance regarding top down policies. All international conflict resolution activities become the target of a critique of their managerial nature; that is, of the tendency to assume the "world-as-it-is" and to promote the status quo (Bellamy and Williams, 2004). Within this critique, local and 'bottom-up' peacebuilding activities can be described as screens that authorize avoiding any questioning of structural conditions or any solution that might call into question international structures (Hromadzic, 2009, 92).

This sociological deploring of an opportunist critical stance (perceived as an insincere critique) can be supported by a richer approach. A sociology of the international circulation of ideas, inspired by Pierre Bourdieu, connects some international practices and policies to the mobilization of precise social groups that seek to consolidate their dominant position in national arenas, and specifically within the political and academic elite circles of the Eastern United States. The positions of these groups within the social hierarchies of their respective countries help to explain the import-export movements of specific international policies or ideas, as in human rights ideas (Dezalay and Garth, 2002) or "democracy promotion" (Guilhot, 2005). The international success in question is more about the success of the given social group than the success of the program, idea, or proposition. The international recognition of dialogue-oriented approaches can also be conceived as an extension or a correction of American foreign policy. The "tracktwo" or "citizen" diplomatic practices of many American agencies might thus appear to complement diplomatic governmental initiatives, allowing for contacts with leaders in groups not yet connected to foreign diplomacy, and introducing deliberative components that are not usual in diplomatic practices. ${ }^{6}$.

\section{The Circulation of Peacebuilding Techniques: Religious, Political, and Professional Mobilizations}

\footnotetext{
5 See the 26 case studies from the Reflecting on Peace Practice Project (for example, Wohgelmuth, 2000) and Anderson and Olson, 2003.

${ }^{6}$ Some of their programs were or are still funded by the American government (those, for example, of the Institute for Multi-Track Diplomacy and the Conflict Management Group, both in Cyprus; or USAID's programs in the Great Lakes region). Some authors see in the goings-on of these « workshops » the «State Department's privatization of entire swaths of American diplomacy for the benefit of politically irresponsible organizations » (Alexis Bautzmann http://www.net4war.com/history4war/dossiers/contemporain/diplomatieUSA3.htm).
} 
This analysis to contemporary forms of international intervention contributes to explain why some programs are multiplying in spite of significant doubts and criticisms regarding their impact on building peace. Yet, no matter how revealing this sociological approach might be, it runs the double risk of reductionism and homogenization.

My goal is thus to defend a sociological approach to the international diffusion of dialogue-based peacebuilding that better reflects the complexity of this diffusion. An historical examination of their "origins" helps to understand their internationalization and their underlying conceptions of social peace. It is a matter of understanding how a particular point of view about peace and peacebuilding gets to be exported. In the case of 'bottom-up' peacebuilding practices, this history of origins is found in the complex articulations and interactions of mobilizations of various groups. ${ }^{7}$ Here, I will discuss only the religious and political origins in the American context to then highlight the proper consequences of the internationalization of 'bottom-up' peacebuilding practices.

As far as the origins of dialogue-based peacekeeping go, religious groups are clearly visible ${ }^{8}$. The policies in question originate directly from the «absolutist» pacifisms of Protestant Anabaptist denominations, particularly the Mennonites, and, more specifically, the liberal elite working for universities and organizations such as the Mennonite Central Committee in Washington, D.C. This group of elites was led to rekindle its pacifist religious leanings (and to renege on a commitment to remain apolitical) in order to defend itself against two separate menaces: first, the American government's threat, brandished regularly throughout the $20^{\text {th }}$ century, to turn military service general, and second, the threat of socio-economic trivialization (urbanization, access to free-market professions previously belonging to people from closed rural communities). The first threat led the Mennonites, along with other "Peace Churches" like the Quakers, to push the American government to adopt a civil service program during both the First and Second World Wars. The civil service experience opened up various forms of social work in prisons, psychiatric hospitals, and abroad (namely peacekeeping aid for countries at war). These experiences became the point of departure of a process of rebuilding of the Mennonite religious identity, as well as of professionalization of an elite.

A second type of origin can be mentioned. The official histories of peacebuilding organizations generally skip over the possible political origins of their group. But most bottom-up peace practices can indeed be traced to a precise political context: opposition to national Cold War policies, and, more specifically, peaceful opposition to American policies -- mostly under the Reagan administration -- that were seen as aggressive. One of the major specialized NGOs, Search for Common Ground, was created in 1982 by John Marks, an independent journalist and former State Department employee who had investigated CIA espionage practices (Marks, 1979). Another organization, the Conflict Management Group, was founded in 1984 by Roger Fisher, father of the win win method of conflict

\footnotetext{
${ }^{7}$ I constructed this history on the basis of over 50 interviews and a proposopographic analysis of approximately one thousand actors. For a partial history of transitional justice, see Lefranc, 2009, and Lefranc and Vairel, 2010.

${ }^{8}$ I will not mention the Quakers, though they are present here as they are in all humanitarian fields.
} 
management and a key figure for the pacifist movement's liberal trend. Both organizations belong to the "educational" component of the $1980 \mathrm{~s}$ pacifist movement in the United States, according to Lofland (1993, 81 and 93), who distinguishes the "educational" approach of groups from others that more directly confront governments. Search for Common Ground's «toolbox » bears faithful witness to Lofland's distinction: the most desirable relation with the adversary is cordial and face-to-face, putting people on a equal footing (Lofland, 1993, 124); "adversarial approaches" (the organization's term) are rejected. In all spheres of social activity (justice included), relations aim for consensus, and cognitive biases are corrected in order to lead to social change.

This brief allusion to some of its origins attests to the heterogeneous nature of the bottom-up peacebuilding sector: liberal Mennonite intellectuals, American diplomats, liberal activists or conservative Evangelicals (an example of this last group will follow), among others, work together to promote an alternative approach of peace. We move yet farther away from the risk of simplification in highlighting the fact that bottom-up international peacekeeping policies are not simply the products of their origins, nor are they the mere products of American culture or political issues. Straightforward though it may be to locate in these programs the handprints of experts from Anglo-Saxon and Protestant reconciliation groups, these experts' convictions can be seen less as the linear transposition of an individualizing evangelical ethos than the concretization of a "Zeitgeist". This "air du temps" is here built by the overlapping of three processes: religious movements, political mobilizations, but also the diffusion of therapeutic and conflict resolution techniques -- developed on the sidelines of public, formal, and professional justice (Lefranc, 2008) -- by professional groups.

Let me give an example of the influence of psychologists: some international peacebuilding programs rely essentially on small group dynamics, role-play, and the transmission of conflict resolution skills. Explicit borrowing is sometimes recognized, like when the specialized evangelical organization, Initiatives of Change, claimed to have been inspired by techniques used by Alcoholics Anonymous, or when the academic founding fathers of conflict resolution invoke applied therapeutic techniques used previously in marriage counseling (Deutsch, Coleman and Marcus, 2006).

It is not a question here of making international programs out to be the simple transposition of an academic discipline or of clinical practices, but rather to insist on the effects of the international circulation of techniques that have been used by groups for the purpose of their professionalization. Many conflict resolution specialists have training backgrounds in mediation or in psychology; many of them continue to work on post-violent conflicts processes abroad, and at the same time in therapy or conflict mediation in their home countries.

Taken together, these religious and political mobilizations, articulated with the use of psychological and legal techniques, do not constitute a unified field of practice. To be sure, a shared critical stance regarding top down policies, as well as the need to raise international funds, tend to unify the movement ${ }^{9}$. But more

\footnotetext{
9 One interview gave us a significant indication of this. Two of the organizations I studied separately are in numerous ways distinct from one another (one organization is Anglo-Saxon, evangelical, and
} 
decisive is the shared (but more or less publicized) emphasis placed on avoiding politics; political exchanges are conceived as intrinsically dangerous and violent. Peacebuilders, when they are getting professionalized, intend in the same movement to disengage from political activism - as showed most of the interviews realized ${ }^{10}$. Former activist founders of the peacebuilding organizations are now overtaken by a new generation of managers and jurists, who come directly from a university background.

Such a disengagement process implies a de-radicalization and perhaps a depolitization. It is certainly not a matter of coincidence if the religious and political groups actively engaged in international peacebuilding are all characterized by a rejection of politics. Mennonites are impregnated with the doctrine of «nonresistance » to political power. The Evangelicals systematically aim to avoid taking the route of the political (Smith, 1998). And the activists promoting peace via "education" are, from the outset, concerned with reaching peaceful and apolitical consensus. All of these groups, we observe, are concerned with a non-political conflict resolution.

The bottom-up peacebuilding organizations use tools that distance them from their activist origins. They put into play tested scientific and professional techniques, have recourse to routine procedures, stress the acquisition of skills, and welcome professionals whose careers are made in NGOs as well as in intergovernmental institutions or in domestic academic, social work or law sectors.

Bottom-up peacebuilding techniques are not different from other post-crisis international intervention practices. The avoidance of the political, which does not require a real de-politization, ${ }^{11}$ is a general characteristic of humanitarian action (Dauvin and Siméant, 2002, 37 ; Collovald, 2001 ; Ferguson, 1994; Bornstein, 2003). Nevertheless, favoring a peace built by "ordinary people", rather than by a political elite, thanks to psychological and legal resolution techniques (see Lefranc, 2008, for the importance of para-judiciary, mediation, practices) conceived as alternatives to state interventions, tends to accent this "apoliticism". I will show that exploring peacebuilders' conceptions of peace and of society, focusing on the way they analyze social functioning from an individualist and relationist point of view.

\section{Individual therapies, social peace}

\section{An individualist, relationist conception of the social}

has participated to the "Cold war" against communists, the other is an NGO linked to the UN created by a Swiss intellectual from the radical left), planned for a collaboration in 2007 . The initial motivation for the proposal was to raise intergovernmental organizations funds.

10 One example: "Search for Common Ground (SFCG) is a professional activity. It's what defines SFCG's approach [not being activist] : to resolve conflicts, we can't take one side or another. So we don't have enemies. Of course, North-South inequalities are scandalizing, but not in terms of working for SFCG...activism is about being against, and it's absolutely necessary (...) The transformation of conflicts implies that one is not against, like Oxfam. Now I really like Oxfam, I feel close to Oxfam...". Interview of a SFCG staff member, Brussels, February 25, 2005.

${ }^{11}$ E. Bornstein (2003) notes, as J. Ferguson did before her (1994), that bypassing the State as an institution does not mean avoiding links with state power and officials, and can be a mean to define new forms of state interventions; 
Though heterogeneous, these peacebuilders disseminate singular and partially unified conceptions of conflict and peace: they all consider that sustainable peace is supported by individuals -- and not by a group or government -- who build, through their interpersonal relations, a "peace culture". These individualist beliefs have formalized, academic counterparts: the social psychology hypothesis of contact, plus techniques from the conflict resolution discipline used to correct prejudices and to construct agreements. Well-rooted individualist and relationist assumptions partly explain why the implementation of peacebuilding programs is not questioned, even when stakeholders have doubts regarding their efficiency, or state their failure.

While diplomatic negotiations, military operations, and post-conflict institutional reforms of state agencies, are intended to dissuade political elites from using political violence, peacebuilders consider that coexistence can be restored through the reform of social functioning and beliefs, which have been affected by a "war culture" and by a tendency to dehumanize the antagonist group ${ }^{12}$. From one hand, truth commissions attempt to encourage the most part of the society to adhere to their historical "truth". From the other hand, meetings and training sessions that gather a small number of « ordinary people », are meant to modify the cognitive and emotional representations of those present. Those modifications should then affect close relations (from the "beneficiary" to her husband, from this man to his mother, from this woman to her neighbor...), and ultimately to all of society.

Indeed, international peacebuilding practices seem to aspire to a true "conversion" of individual stakeholders: at the least, thanks to a re-evaluation of recent history, at the most, through the total upheaval of the individual's relation to the Other and to the conflict. The conversion takes place via direct, interpersonal, face-to-face discussions with the adversary. Though a third party may be present as facilitator, he must not impose nor sanction anything.

Three hypotheses seem to underlie these practices, and I will now present them in general terms before presenting briefly specific peacebuilding programs.

At the heart of most of the dialogue-based peacebuilding practices lies the hypothesis that the individual is the motor for social change, and thus the only true peacemaker. Reconciliation is defined by a psychologist as "a profound cognitive change" on the level of each individual: "the essence of reconciliation involves socio-psychological processes consisting of changes of motivations, goals, beliefs, attitudes and emotions by the majority of society members" (Bar-Siman-Tov, 2004, 12). The circumventing of the elites is thus not only a pragmatic solution after noticing that "top-down" policies have failed. It is also a demonstration of peacebuilders' trust in the ordinary individual's capacity to rid himself of his prejudices. Collective group functioning, often portrayed as a largely constrained adhesion to various identity categories manipulated by leaders, is cause for

\footnotetext{
12 Coexistence, or even good relations, together with voluntarist intermingling of groups, nevertheless do not appear to rule out political plans to eliminate groups, nor violent acts on the part of former neighbors. See Bauman, 2002, on the Jewish genocide, Hatzfield, 2007, Straus, 2006, and Vidal, 1998 , on the Rwandan genocide, or Claverie, 2004, on ex-Yugoslavia.
} 
suspicion. At the same time, many of the social attributes do not longer seem to have importance, what impoverishes the sociological understanding of the dynamics of violence. In the organizations' reports as well as in interviews carried out with staff, two kinds of social logics predominate: binary conflicts, usually ethnoreligious, which must be bypassed (thanks to the establishment of mixed groups, for example), and opinion leaderships (exercised by "intermediary" elites, religious leaders, women, children). Complex social hierarchies then largely disappear.

As a result, interpersonal relations, for example "friendships", considered independently from social identities (Hewstone and Brown, 1986), are preferred over political and legal modes of conflict regulation which are based upon norms decreed by third parties. These private and ordinary relations are seen as "sincere" (contrary to political relations, always judged as insincere and purely instrumental), and personal; as such, they create a sustainable peace. Landrum Bolling, director at large of Mercy Corps/Conflict Management Group, discusses a program, based on the concept of the interpersonal relation, that he established at Earlham College, a Quaker institution: "To me, this is crucial. There is no substitute for direct face-toface acquaintance with other people and other cultures"13.

A corollary of this promotion of person-to-person relations is a particular way of explaining social change. Metaphors like "critical mass" or "critical yeast" (Lederach, 2005) are apt illustrations. Starting with modified representations amongst a small group of individuals, which then spread to larger groups, social change happens more or less mechanically, and is more or less dependant on structural socio-economic and political reforms occurring at the same time. Various vectors ensure that local changes are diffused through the whole group: either by way of example (the "heroes" of Studio Ijambo's radio show in Burundi -- a Search for Common Ground initiative) or via the strength of a few "civil society" organizers and activists (the main beneficiaries of these programs are, indeed, association managers). Diffusion is also guaranteed by targeting future elites and opinion leaders, political moderates, "spoilers", or groups considered as linkage points between two social groups (women, for example).

These diffusion mechanisms are grounded on a unique conception of peaceful society. Bottom-up peacebuilding practices (as they are used, for example, during sporting and artistic events, in conflict resolution workshops or training programs, or even in places like daycares, school, and business) intend, as a whole, to revitalize daily inter-group relations between ethnic, religious, or regional factions. Deemed crucial, these interactions might take place in the neighborhood, in the workplace, or during leisure activities. Professional, sectoral, even political, all are viewed as interpersonal relations ${ }^{14}$. And in this way, what may emerge is a "new ethos embedded within a culture of peace" (Bar-Simon-Tov, 2004, 37).

If it is true, and many peacebuilders, do think it is, that all social relations

\footnotetext{
13 Interview, Washington, D.C., February 23, 2007.

14 Even media-based programs promote concrete person-to-person relations. In Burundi, for example, two former militia leaders, one Hutu and one Tutsi, were interviewed during a radio show produced by Search for Common Ground. Funding was provided for potential young leaders from the two groups to get together in order to prevent a new young militiamen recruitment campaign by politicians. The dialogue was then pursued by an association that organizes soccer tournaments, among other events. Interview, Brussels, February 23, 2005.
} 
consist in a chain of interpersonal relations, then it is no longer necessary to conceive of social functioning as differentiated between social sectors and scales (for a sociological theory focusing on such a sectoral differentiation, see Dobry 2010). All forms of social exchange, including conflicts, are contained within a single continuum. All disputes, from domestic violence to civil war, can even sometimes be said to come from the same sources (a "culture of violence", for example). It then becomes easier to understand why certain international organizations like the NGO World Vision (evangelical protestant in origin) aim to contribute to political domestic peace via the regulation of minor disputes (in this case, disputes between parents and children ${ }^{15}$ ), and why other groups, like the British Conciliation Resources (in Angola, for example) or the United States Conflict Management Group (in Rwanda) train community members in conflict resolution techniques so that they may become "peace monitors" tasked with resolving local disputes (familial conflicts, land disputes, issues dealing with the return of refugees, and so $\mathrm{on}^{16}$ ). And if all of these conflicts find their roots in the same interpersonal relation "failures", then those same methods used successfully for the resolution of marital discord (or even inner turmoil) might also be implemented to resolve mass conflicts. This hypothesis regarding the continuum of all forms of social exchange -- harmonious or violent -is explicitly formulated in the specialist, scientific literature that may have partially inspired the policies in question here (see, for example, Deutsch, Coleman et Marcus, 2006, xii, 8, 268). We should retain here only a very condensed statement from a North-American family therapist: "Inner peace and world peace are, at root, one and the same (...) We can apply one basic approach to self-help and to helping others, to resolving personal conflicts and to ending social strife" (Breggin, 1992, $3)$.

Experts and practitioners of dialogue-based peacebuilding offer a response to an enigma that still confounds sociologists; the enigma of the "infinitely tiny steps" that, when repeated, form the "grand total", and build a solid social tissue (Simmel, 1999 (1908), 56). But this enigma, along with progress made in the social sciences toward overcoming individual/social structure-type dichotomies, are pushed aside. In their place, evidently incompatible with them, are privileged certitudes regarding the individualistic nature of social exchanges and the existence of a continuum of social relations from diverse sectors and scales. The peace that is aimed at here consists in a "psychology of cooperation" (Bar Tal and Bennink in Bar-Siman-Tov, 2004,22 ) that is set up in "flat" and horizontal societies by the means of a "deep change in the public's psychological repertoire" (ibid., 17). To illustrate the functioning of dialogue-based peacebuilding programs, I turn now to several examples.

\section{The Peace of Individuals: Therapeutic Techniques for Bottom-Up Peacebuilding}

This individualistic conception of the social is well-illustrated in bottom-up

\footnotetext{
15 Active participation in schools, along with dialogues with the police and other authorities, would consolidate and encourage harmonious relations between parents and their children. See World Vision, 2001.

${ }^{16}$ Conciliation Resources, 2004, and interviews from May 23, 2006 at the organization headquarters, London.
} 
peacebuilding practices of certain religious organizations. Surely a good example is the international organization, Initiatives of Change, that finances peace education programs for schools, peace-oriented leaders training programs, intercultural dialogues, and women's groups. The programs all work toward the construction of peace, in the "South" (poor countries trying to exit violent conflicts) as well as in the "North" (richer countries experiencing social conflicts, where, for example, in the United States, the organization implements "racial healing" programs in various communities).

The organization is labeled as an NGO, cooperating with inter-governmental organizations and think tanks. In reality, though, the organization is the avatar, the last form taken by a group known under the name of Moral Re-Armament (MRA). Created by Frank Buchman (1878-1961), the group was initially evangelical, recruiting members in Great Britain, later in the United States and then in other world nations. They were quick to define their mission statement as peacebuilding (in Morocco, in Rhodesia, in various companies, and so on) based on individual conversions thanks to interpersonal relations. The one-by-one shifting of people minds, regardless of their social or political backgrounds, is supposed to allow for change on a national and worldwide scale. Peace needs to be won through "unexpected encounters" (Piguet and Sentis, 1979, 45) and by individual "conversions" to peace as well as, often, to evangelical Christianity. The organization's keystone event stands as proof of their mission: conferences, held at a grand old hotel in Caux (Switzerland), encourage former enemies to recount the story of their conversion to peace, and then to dialogue about it together in pairs.

Similarly targeting individual conversions, the Moral Re-Armament actively fought against communism in the Cold War. MRA activists attempted to convert communists and socialists (encouraging them to join and to de-ideologize their positions), organized meetings between syndicate leaders and CEOs, promoted a consensual mindset regarding industrial disputes, and so on.

Like the evangelical groups, Initiatives of Change members want individuals to be "born-again" into peace thanks to interpersonal relations. The change should occur as a result of individual relations, one by one, as well as by following the example provided by the good Christians ("good men make good societies", Lewis Smedes cited in Smith, 1998, 191). For the North American Evangelicals, this "relationism", based on an individualistic conception of faith, implies a strategy of evangelization via personal influence (Smith, 1998). Potential structural solutions along with the possibility of forming a collective political position are bypassed in favor of this conception.

Upon observing the practices of Initiatives of Change in Colombia (the group, Iniciativas de Cambio, has existed for about twenty years but is only just now beginning to get on its feet) it seems possible to confirm both the avoidance of the political and the "flattening" of the social discussed earlier. Peacebuilding is supposed to result from meetings of small groups of members/believers recruited from a pool of close relations. Meetings are held at a member's home (the group interviewed in this chapter is entirely female), and during the session, each person takes her turn to tell how she joined the group. A conversion is indeed always in question, even if the members may belong to distinct religious groups. The individual conversion narrative is not only seen as the trademark of the group, but also as a powerful vector of peace at a country level. A case in point: one woman, 
another participant's housekeeper and a member of one of the lowest social strata (the seven estratos correspond to urban zones, and, by extension, to different social classes; they are well-established and discussed with ease in Colombia), told during the meeting of her difficulties in surmounting feelings of social inferiority and of hostility toward "those who have money". She described battles with her partner, he more spiteful than she -- and told of the time she accepted an offer to share a bedroom and bathroom with her employer during one of the group's "retreats". And she spoke of appeasement; if not her complete acceptance of social inequalities, then a suspension of the criticisms she had tended to make. She came to realize that the most privileged in terms of resources were not always "the responsible ones" $^{17}$. These conversion narratives, which speak of transformations thanks to direct connections with people living by the moral principles Frank Buchman set out in the 1930's, constitute, along with readings from "inner voice" diaries, the framework for the group. As with therapy groups, tears, hugs, and embraces are sought after, and all of the techniques for valuing the individual are put into practice.

But one would be mistaken in drawing a straight line from these practices, a mixture of therapy treatments and religious rituals, to evangelical credo. All of the peacebuilding practices, taken together, aim toward reforming individual behaviors. A second example, taken from a universe far from that of Initiatives of Change, will discuss the summer camps created by Seeds of Peace, an organization founded in 1993 by non-religious (and even non-believing) Jews.

Seeds of Peace was founded in the United States by the Washington journalist, John Wallach, with the help of a social worker, Barbara Gottschalk, and an African-American teacher and sports trainer, Tim Wilson. The cornerstone action of the group is a three-week summer camp in Maine where several dozens of adolescents aged 14 to 17 gather together, all from ethnic or national groups in conflict. Israelis, Palestinians, and young people from other Arab countries make up the bulk of participants. But there is also youth from the Balkans, from Cyprus, Greece, Turkey, India, Pakistan, Afghanistan, and, more recently, the United States (some of them originating from Arab countries). Dressed in the same green tee shirts printed with an olive branch, the campers share cabins and showers, eat and play sports together and attend other campers' religious ceremonies. On "Culture Night", they partake in fellow campers' national rituals and exchange traditional garb, cuisine, and music. Players from mixed countries face off in sporting competitions. And each day, split up into groups of 10 to 12 campers from groups involved in a specific conflict, the young people engage in mandatory half-hour-long "Coexistence sessions", during which they share "personal accounts that test prejudices" (Seeds of Peace, 2006, 4) and discuss the "most sensitive and difficult questions and look for a common grounds" (ibid, 6). Speaking exclusively in English, they discuss the conflict directly, touching upon its everyday consequences and the feelings it gives rise to. In the company of "facilitators" (professionals from United States or from countries torn by conflicts) and "counselors" (former campers turned psychological supports), they learn "listening techniques", applauding heartily, hands held tight together. They also participate in games like the

\footnotetext{
${ }^{17}$ This woman had been introduced to me before the meeting by her employer as unique in the sense that she was someone who managed to «like women like us ». Observation, November 2007, Bogotá (Colombia).
} 
"timeline", where the group's most significant historical events are determined and recorded on either side of the line.

There are numerous similarities between Initiative of Change's activities and those of Seeds of Peace. At Seeds of Peace, hugs are also encouraged: " Although romance at the camp is forbidden, hugs are encouraged as confirmation of friendship" (Chess Feller, 1999). The individual is highly valued: the teenagers "learn that they count" (Wallach, 2000, 112). Friendships developed during games or during coexistence sessions at the Maine camp are perceived simultaneously as the result of individual "conversions" and as individual healing processes: thus it is possible to present the American public with "moving testimonials structured like stories of religious awakening or secular 'enlightenment': A journey from ignorance and darkness to seeing the light" (Lazarus, 2006, 18). And yet it would be incorrect to attribute these programs' marked individualistic approach only to a largely religious, therapeutic American ethos (Nolan, 1998). The strength of these therapeutic techniques is rather the fact that they attract many different groups from various social sectors, united in the name of policies deemed alternative. In Colombia, other, politically distinct organizations participate in peacebuilding using very similar techniques. A Jesuit organization with links to Liberation theology employs worker-activists trained in psychology to build groups made up of local community organizers and of victims from all over the country. Games (role play, drawing) and dialogue are used to design peace sessions for them. Embracing each other, group members learn to draw the line connecting the three dimensions considered as vital to the existence of peace: individual development, interpersonal relations, and -- this is a distinctive trait -- collective organization ${ }^{18}$. It is clear, then, that similar techniques circulate, often borrowed from different direct sources ${ }^{19}$, throughout distinct organizations. During international circulation, the techniques are mutually reinforced.

According to Hammack, the summer camp programs tend to frame conflict as created primarily by individual prejudices. Conjointly, intervention in personal development -- more so than within social structures -- may contribute to social change. He attributes this framing to the influence of the social sciences in the United States after the Second World War, and, more specifically, to social psychology based on the intuitions of Gordon Allport (Allport, 1954): "Americanbased efforts at peace education are fundamentally rooted in an American folk psy about identity and intergroup relations" (Hammack, 2009, 128). As a result, these peacebuilding policies via interpersonal contact come up against the same limits as would a social psychology that is insufficiently sociological. They fail to generalize specific attitudes (Hewstone and Brown, 1986, 17 sq.). Hammack also notices that after the initial enthusiasm of having made new friends, identities become opposed anew, once more alienating the summer camp participants.

\section{Transitional justice: De-Politicizing Victims}

\footnotetext{
18 Training workshop observation and interview, Bogotá, November 2007.

19 The Catholic psychologists mentioned here draw their inspiration from -- or least rationalize their practices with -- "critical" psychological theories assimilated in academia, sources that are very distinct from those connected with Initiative of Change or Seeds of Peace.
} 


\section{Private grieving policies}

The individualist and relationist premises of the bottom-up peacebuilding practices, constitute a trend extending beyond traditional individualist organizations. This contemporary ethics affects peacebuilding policies that seem to take a much more political, institutionalized approach. Such is the case for "transitional justice".

Truth commissions are known internationally for their supposed capacity not to build an "official" and consensual truth, but to come up with a telling of events that is acceptable according to the largest number of people; the story needs to be pluralist-, even "dissensual" (Osiel, 2002 ; Ricoeur, 2003), that is, constructed on the basis of a diversity of versions -- beginning with the victim's.

Generally speaking, it is only under certain conditions, though, that these commissions make room in their programs for public testimonies from victims. The first Latin American truth commissions used a closed-door testimony approach and cited heard victims only selectively in reports (in Argentina and Chile, for example). Public testimonials discredit any political expression of grief, ceding instead to the public articulation of individual suffering, moral suffering indeed, like the kind of suffering undergone by a mother who has lost a « disappeared » child. In cases like these, reconciliation policies appear as policies set in place in order to facilitate survivors' "grieving process".

What is established, then, in order to address reparations and accord public recognition to victims, is not so much a contradictory, judiciary examination of who may have been guilty, but rather a kind of political grief management: the administrative recognition of the death of "disappeared" people in Argentina, for example, or the government policies on body exhumation and restitution in Chili, under the Lagos government, that could exempt information providers from judicial procedures.

The idea is not always accepted by the victims' relatives. The Argentinean Mothers of the Plaza of Mayo, led by an incontestably politically "radical" Hebe de Bonafini, have fought since 1983 against government-proposed reparation policies in order to counter what they perceive as a de-politicized reading of the past.

"We the Mothers of the Plaza de Mayo know that our children are not dead; they live in the fight, the dreams, and the revolutionary engagement of other young people (...). We (...) reject the exhumations because our children are not corpses. Our children have physically disappeared, but they are still living in the fight, the ideals, and the engagement of those who are fighting for justice and the liberation of their people. That which remains of our children must stay where our children fell. There cannot be any tomb that shuts up a revolutionary (...). We refuse plaques and monuments because they aim to bury the dead. The only possible homage is to raise the battle flag and continue on our way. ${ }^{20}$

20 "Nuestras consignas", Internet page (www.madres.org), n.d. 
Constructing a version of History that is sufficiently consensual in order to work toward peacebuilding implies that both governments and truth commissions conceive the particular society's past in terms of suffering. Facts are exposed, but issues regarding political legitimacy are avoided because they are sources of disagreement.

First and foremost, the suffering of the victim is taken into account, but also the suffering of all of the others -- perpetrators included. The victim is not he or she who defended a just or unjust political cause and lost (vanquished but not assaulted opponents are not considered victims). He or she is the one who, no matter the cause in question, has suffered. The Rettig Commission in Chili, for example, considered "fallen" soldiers as victims, even outside of their rare confrontations with guerilla fighters; the commission's mandate stipulates this (Lefranc, 2002).

The figure of the victim emerges in the moral sense of the term, taken in consideration with a physical or psychological suffering independent of the context it was provoked in. In a way, political conflict is boiled down to its physical wounds, its moral and psychological damages. This point of view is not without consequences, though, at least not in the period initially following the conflict: in view of the need to recognize and soothe suffering -- the suffering, for example, of mothers who cannot enter the "grieving process" because there are no corpses to mourn -governments capitalize on the utility of knowing and publicizing facts, not so much rendering justice. Most "transitional" governments have insisted on the moral necessity for "truth", truth about the fate of disappeared children, and about the location of their bodies. The first reparations are thus constituted by truth itself, and, when possible, the restitution of bodies. The primary goal is not to have sociopolitical groups confront in a public space their political and conflicting conceptions of the past, but to permit disappeared persons' close relations to enter, individually, and in a private space, into a "grieving process".

\section{De-politicizing and de-juridicizing conflicts surrounding the past}

The victim's testimony is further constrained by two convergent characteristics. On the one hand, most truth commissions are marked by attempts to neutralize political conflicts, for example in devising a political representativeness of the commissions' members meant to neutralize divergences, or in electing persons already distanced from politics (as are supposed to be clergymen) and who have often been chosen because of certain professional competencies (jurists, historians, psychologists...). Via truth commissions, and, more broadly speaking, via a system of "transitional justice", governments or international organizations appoint well-reputed private individual actors to carry out reform work on a given society's relation to its past. This avoidance of politics -- and avoidance, for example, of elected members of Parliament -- can be explained both by underlying and purely circumstantial reasons. On the one hand, the period of "transition" toward democracy and peace is well-suited for the silencing of political conflicts, and all the more so when the transition has been allowed by a compromise between "newcomers" (new democratic governments, for example) and "outgoing" actors (agents from violent authoritarian regimes). On the other hand, contemporary 
democratization and peacebuilding processes occur in a context where state reconfiguration and de-legitimatization of political action and discourse have been deeply rooted.

Notwithstanding attempts by advocates of transitional justice to make of it for a component of the international criminal justice system, truth commissions can still be seen, largely speaking, as an effort to rationalize and legitimize a political compromise providing amnesty to agents of violence (sometimes subversively - for example when they introduce the question of forgiveness, allowing activists to turn the argument against the government, for example recalling that only the victims can forgive). The commissions often contribute to a sanctioning of reparations ${ }^{21}$ rather than systematic judiciary proceedings, bolstering an alternative principal of justice such as restorative justice (Lefranc, 2009). Transitional justice thus promotes justice that is under weaker state control and less formal, with a larger place set aside for victims.

\section{Conclusion}

The recourse that peacebuilding organizations have had to individual, psychological therapeutic techniques reflects these groups' historical origins. On the one hand, it speaks to individual trajectories of disengagement and professionalization when certain agents find themselves at a crossroads between the legal and the psychological spheres. On the other hand, it speaks to the very reconfiguration of international intervention approaches that circumvent political action and institutions. But this avoidance of the political processes may only be appearance. For in the same way that de-politicized, anti-state power development tactics remain tied to State power (Ferguson, 1994 ; Bornstein, 2003), professional peacebuilding practices remain within the sphere of political engagement. Seeds of Peace, for example, remains a political mobilization by liberal Jews favoring the establishment of a Palestinian state via alliance strategies with "moderate" OLP leaders. The group seeks an alternative to the "pro-Israel lobby" embodied by the America-Israel Public Affairs Committee. Even its activities are political, for example when it selects, accompanies and trains future leaders (a process facilitated by the presence in the summer camp of many senior officials' children. What is more, truth commissions and peacebuilding programs have largely been « re-politicized ». Social and political groups with specific interests have invested in and then used the institutions and practices as arenas for conflict. For example, some groups of politically mobilized victims of human rights violations, far from the silence expected from moral individual victims, have been noisy and have contributed to such a politicization.

This brand of political avoidance nonetheless leads to a "flat" conception of the way societies function; as if a chain of direct relations linked individual to individual. As a result, a very particular, and yet familiar, conception of the causes

\footnotetext{
${ }^{21}$ Compensations, an easier access to medical services, academic scholarships, children of disappeared persons' option to skip military service and the rehabilitation of the deceased (those who yesterday were "subversive » becoming victims) determining the circumstances of victims' death, re-inhuming them, constructing memorials, and so on.
} 
for violence acts is spread and reinforced: a « peace culture » (as opposed to "war" or "violence" culture) is favored over structural causes like the various factors that may have emerged while leading up to the violent act ${ }^{22}$.

Individual representations are forming, while they are disseminating through interpersonal relations, a collective culture which is supposed to determine, in return, if people are, or are not, going to act violently. We are then faced with a certain brand of the widely-spread hypothesis positing that a large-scale modification of representations (here, via direct "contact" or via changing prejudices or narrations of History) can contribute to forestalling political violence. The hypothesis require a re-examination. Social psychologists (Hewstone and Brown, 1986 ) along with historians (Bauman, 1989; Browning, $1992^{23}$ ) prompt us to do this when they underline two facts. First, that conflict brings groups to the fore (individuals acting as members of groups) instead of individuals free from any social constraint. Second, neither a "cognitive" relation to the past (knowledge of prior periods of extreme violence or civic education) nor adherence to humanistic values can provide reliable fortification from political collective violence.

22 Dobry, 1995, stresses the «emergent norm» characteristic of violence or non-violence. This characteristic has more weight than the tactical motivation involved, and yet even more than the ethical orientations of a small number of actors.

${ }^{23}$ But also social psychology investigations like Latané, 1970, or Datley and Batson, 1973. 


\section{Bibliographic References}

Abu Nimer M., ed., 2001 Reconciliation, Justice, and Coexistence. Theory and Practice, Lexington Books, Lanham.

Allport G. W., 1954, The Nature of Prejudice, Londres, Addison-Wesley.

Anderson M. and Bock J. G., 1999, « Dynamite Under the Intercommunal Bridge : How Can Aid Agencies Help Defuse Violence? », Journal of Peace Research, 36(3), 325-38.

Anderson M. B. 1999, Do no Harm: How Aid Can Support Peace-or War, Boulder, Colo., L. Rienner.

Anderson M. et Olson L., 2003, Confronting War. Critical Lessons for Practitioners, Cambridge, CDA.

Bar-Siman-Tov Y., ed., 2004, From Conflict Resolution to Reconciliation, Oxford, Oxford University Press.

Bauman Z., 1989, Modernity and the Holocaust, Cambridge, Polity Press.

Bellamy A.J. and Williams P., 2004, «Introduction: Thinking Anew about Peace Operations », International Peacekeeping, 11(1), spring, p. 1-15.

Bornstein E., 2003, The Spirit of Development. Protestant NGOs, Morality, and Economics in Zimbabwe, New York, Routledge.

Breggin P. R., 1992, Beyond Conflict? From Self-Help and Psychotherapy to Peacemaking, New York, St Martin's Press.

Browning C. R., 1992, Ordinary Men : Reserve Police Battalion 101 and the Final Solution in Poland, New York, HarperCollins.

Chapman A. and van der Merwe H., ed., 2008, Truth and Reconciliation in South Africa : Did the TRC Deliver?, Philadelphia, University of Pennsylvania Press.

Chess Feller L., 1999, «In Search of Peace on Common Ground », New York Times, 28 august.

Claverie E., 2004, « Techniques de la menace », Terrain, 43, 2004, 15-30.

Collovald A., 2001, «De la défense des "pauvres nécessiteux" à I'humanitaire expert. Reconversion et métamorphoses d'une cause politique », Politix, 14 (58).

Conciliation Resources, 2004, Annual Report 2003, London.

Cooke B. and Kothari U., ed., 2001, Participation: the New Tyranny?, London, Zed Books.

Datley J. M., et Batson C. D., 1973, «From Jerusalem to Jericho. A Study of Situational and Dispositional Variables in Helping Variables », Journal of personality and social psychology, 27(1), 100-108.

Dauvin P. and Siméant J., 2002, Le Travail Humanitaire : les Acteurs des ONG, du Siège au Terrain, Paris, Presses de Sciences Po.

David C.P., 2000, La Guerre et la paix. Approches contemporaines de la sécurité et de la stratégie, Paris, Presses de Sciences Po.

Deutsch M., Coleman P.T., Marcus E.C., ed., 2006 (2d ed.), The Handbook of Conflict Resolution. Theory and Practice, San Francisco, Jossey-Bass.

Dezalay Y. and Garth B. G., 2002, The Internationalization of Palace Wars: Lawyers, Economists, and the Contest to Transform Latin American States, Chicago, Ill./ London, University of Chicago Press.

Dobry M., 2010, Sociologie des crises politiques, Paris, Presses de Sciences, 2d ed., revised.

Dobry M., 1995, « Les causalités de l'improbable et du probable : notes à propos des manifestations de 1989 en Europe centrale et orientale », Cultures et conflits, 
17, spring, 111-136.

Ferguson J., 1994, The Anti-Politics Machine: "Development", Depoliticization and Bureaucratic Power in Lesotho, Minneapolis, University of Minneapolis Press.

Guilhot N., 2005, The Democracy Makers: Human Rights \& International Order, New York, Columbia University Press.

Hammack P. L., 2009, «The cultural psychology of American-based Coexistence Programs for Israeli and Palestinian Youth », in McGlynn C., Zembylas M., Bekerman Z. et Gallagher T., ed., Peace Education in Conflict and Post-Conflict Societies. Comparative Perpectives, New York, Palgrave MacMillan.

Hatzfeld J., 2007, La Stratégie des antilopes, Paris, Le Seuil.

Hewstone M. and Brown R., ed., 1986, Contact and Conflict in Intergroup Encounters, Oxford, Basil Blackwell.

Hromadzic A., 2009, «Smoking doesn't Kill; it Unites! Cultural Meanings and Practices of "Mixing" at the Gymnasium Mostar in Bosnia and Herzegovina », in McGlynn C., Zembylas M., Bekerman Z. et Gallagher T., ed., Peace Education in Conflict and Post-Conflict Societies. Comparative Perpectives, New York, Palgrave MacMillan.

Latané B., 1970, The Unresponsive Bystander: Why doesn't he help?, New York, Appleton-Century Crofts.

Lazarus N., 2006, « The Political Economy of Seeds of Peace: A Critical Evaluation of US-Based Civil Society Conflict Intervention», paper, International Studies Association, San Diego, march.

Lederach J. P., 2005, The Moral Imagination: the Art and Soul of Building Peace, Oxford/New York, Oxford University Press.

Lefranc S. et Vairel F., 2010, «The Emergence of Transitional Justice as a Professional International Practice", in Israël L. et Mouralis G., Transitions, Vetting, Ends of War, to be published.

Lefranc S., 2006, «Le mouvement pour la justice restauratrice : "an idea whose time has come" », Droit et société, 2 (63), 393-409.

Lefranc S., 2009, « La professionnalisation d'un militantisme réformateur du droit: I'invention de la justice transitionnelle », Droit et société, 73, p. 561-589.

Lefranc S., 2002, Politiques du pardon, Paris, Presses universitaires de France (transl. into Spanish, 2004, Catedra, Madrid, 2005, Norma, Bogota).

Lofland J., 1993, Polite Protesters. The American Peace Movement of the 1980s, New York, Syracuse University Press.

Marks J., 1979, The Search for the "Manchurian Candidate": the CIA and Mind Control (New York, Times Books.

McDonald J., 2002, «The Need for Multi-Track Diplomacy », p. 49-60 in Davies J. and Kaufman E., ed., Second Track/Citizen's Diplomacy. Concepts and Techniques for Conflict Transformation, Lanham, Rowman \& Littlefield.

Mi'Ari M., 1989, «The Effect of the Uprising on Readiness for Interethnic Contact Among Palestinians in Israel », International Journal of Comparative Sociology, XXX (3-4), 238-246.

Nolan J.L., 1998, The Therapeutic State. Justifying Governement at Century's End, New York, New York University Press.

Osiel M., 1997, Mass atrocity, collective memory, and the law, New Brunswick, N.J., Transaction.

Paris R., 2004, At War's End. Building Peace After Civil Conflict, Cambridge, Cambridge University Press.

Piguet C. and Sentis M.J., 1979, Ce monde que Dieu nous confie. Rencontres avec le 
Réarmement moral, Ed. du Centurion, Paris.

Ricœur P., 2000, La Mémoire, I'Histoire, I'Oubli, Paris, Le Seuil.

Search for Common Ground, Abdalla A. K. et al., 2002, Independant Programme Evaluation, Search for Common Ground in Burundi 1999-2001, April.

Seeds of Peace, 2006, Annual Report 2005, New York.

Simmel G., Sociologie. Etudes sur les formes de la socialisation, Paris, Presses Universitaires de France, 1999 (1908).

Smith C. et al., 1998, American Evangelicalism. Embattled and Thriving, Chicago, The University of Chicago Press.

Sommers M. et McClintock E., 2003, « On Hidden Ground. One Coexistence Strategy in Central Africa », p. 35-58 in Chayes A. et Minow M., Imagine Coexistence. Restoring Humanity After Violent Ethnic Conflict, Jossey-Bass/PON Harvard Law School.

Stephan W. G. and Stephan C. W., 1996, Intergroup Relations, Boulder, Westview Press.

Straus S., 2006, The Order of Genocide: Race, Power, and War in Rwanda, Ithaca, Cornell University Press.

Truth and Reconciliation Commission / Department of Justice, 1999, Truth and Reconciliation Commission of South Africa Report, Londres, MacmillanReference / New York, Grove's Dictionaries.

Tutu D. M., 1999, No future without forgiveness, London, Rider.

Vidal C., 1998, «Questions sur le rôle des paysans durant le génocide des Rwandais tutsi », Cahiers d'études africaines, 38 (150-152), 331-345.

Wallach J., 2000, The Enemy Has a Face: the Seeds of Peace Experience, Washington, D.C., United States Institute of Peace Press.

Wohgelmuth L., 2000, NGOs and Conflict Prevention in Burundi. Reflecting on Peace Practice Project, Case Study, Cambridge, CDA.

World Vision, 2001, Children and Peacebuilding. Experiences and Perspectives, Melbourne, World Vision. 